\title{
An evaluation of utility of Jatropha curcas L. as a source of multiple energy carriers
}

\author{
Raphael M. Jingura ${ }^{1 *}$, Downmore Musademba ${ }^{2}$, Rutendo Matengaifa ${ }^{2}$ \\ ${ }^{1}$ Chinhoyi University of Technology, Research Directorate, P. Bag 7724, Chinhoyi, ZIMBABWE \\ ${ }^{2}$ Chinhoyi University of Technology, School of Engineering Sciences and Technology, Department of Fuels and Energy, P. Bag 7724, Chinhoyi, ZIMBABWE \\ *Corresponding Author: e-mail: rjingura@cut.ac.zw, Tel +263 712884342
}

\begin{abstract}
Jatropha curcas L. (JCL) is a popular energy crop in tropical countries. The crop has multiple uses including supply of energy. The major source of energy from JCL the seed oil, which can be used in the raw form or as biodiesel. Biodiesel is a first generation energy carrier. Other products obtained from JCL during its production and processing include wood, fruit shells, seed husks and press-cake. Not much attention has been paid to the energy value of these components. This paper reviews the energy norms of these components and their energy value. Technologies exist to convert these into liquid, gaseous and solid energy carriers. The technologies include anaerobic digestion, pyrolysis, gasification, trans-esterification and combustion. Use of these technologies can optimize the utility of JCL as a source of multiple energy carriers. There is need for integration of the available and distributed data, knowledge and experiences on use of JCL as an energy source into an aggregated discourse. This paper attempts to review the available information on the use of JCL as a source of multiple energy carriers with the objective to provide a complete analysis of the potential energy value of JCL.
\end{abstract}

Keywords: Jatropha, biomass energy, conversion technology, energy carrier

\section{Introduction}

Biomass is attracting great attention over the world as a source of renewable energy as well as an alternative to fossil fuels. Biomass resources supply over 14\% of the world's energy needs (Demirbaş and Demirbaş, 2003; McKendry, 2002). The attraction for biomass has been premised on the following: ease of its production; sustainable supply advantages; and environmental benefits. Several crops are being grown in energy crop farming as feedstocks for first generation biofuels. Jatropha curcas L. (JCL) has been identified as the most suitable energy crop in tropical regions (Del Greco and Rademaker, 1998).

The JCL plant is currently receiving a lot of attention as an energy plant (Kumar and Sharma, 2008). Jatropha curcas is a plant that belongs to the family Euphorbiaceae. It is a shrub which can reach a height of $5 \mathrm{~m}$, but can grow up to $10 \mathrm{~m}$ under favourable conditions (Kumar and Sharma, 2008). It is a vigorous drought and pest-tolerant plant that can grow on barren and eroded lands under harsh climatic conditions. It is easily established and grows very quickly. Jatropha curcas produces non-edible oil. The shrub starts bearing fruit from the second year of planting. If managed properly, JCL starts producing 4-5 $\mathrm{kg}$ of seeds per tree from the $5^{\text {th }}$ year onwards and the plant has longevity of 40-50 years (Singh et al., 2008). The shrub has multipurpose uses and many attributes that give it considerable potential for energy uses.

The major energy carriers from JCL are the raw oil and its esters. The utility of JCL oil and its esters as replacements for petrodiesel has been well documented (Kywe and Oo, 2009). The technologies used to convert JCL into mainstream energy carriers have mainly concentrated on mechanical and chemical processes focusing on seed oil. However, JCL is a robust energy plant, which in addition to seed oil, also produces wood, fruit shells, seed husks and press-cake. These are potential sources of additional energy carriers in a zero-waste bioenergy system for JCL. Several energy conversion technologies can be used to derive solid, liquid and gaseous energy carriers from JCL and the by-products of its processing. This would optimize the energy value of JCL. The technologies include anaerobic digestion, pyrolysis, gasification, trans-esterification and combustion. 
Several studies have been carried out on the holistic approach to utilize JCL as a source of multiple energy carriers (Singh et al., 2008; Gunaseelan, 2009; Vyas and Singh, 2007). These studies have focused on possible energy carriers from seed oil, fruit shells and seed components. However, there is need for integration of the available and distributed data, knowledge and experiences on use of JCL as an energy source into an aggregated discourse. This paper is an attempt to review the available information on the use of JCL as a source of multiple energy carriers with the objective to provide a complete analysis of the potential energy value of JCL.

\section{Energetic components of Jatropha curcas L.}

The components of JCL from which energy can be derived are wood, fruit shells, seed husks and kernel (Singh et al., 2008). A schematic illustration of the production of these components is shown in Figure 1. Jatropha curcas produces oil-rich fruits. The fruit is made up of the outer shell and seeds. Fruit yields average about $3.5 \mathrm{t} \mathrm{ha}^{-1}$, and when grown under rainfed conditions in wastelands, yields of 1-1.25 $\mathrm{tha}^{-1}$ are common (Kumar et al., 2003).

\subsection{The fruit}

On average the JCL fruits are $2.5 \mathrm{~cm}$ long, ovoid and each fruit contains 2-3 seeds. It has nearly 400-425 fruits per kg and $1500-$ 1600 seeds per kg weight (Singh et al., 2008). Dry JCL fruit contains about 35-40\% shell and 60-65\% seed by weight (Vyas and Singh, 2007). The seed is made up of about $42 \%$ husks and 58\% kernel (Abreu, 2009, Singh et al., 2008). On fruit weight basis, JCL contains about 17-18\% oil (Signh et al., 2008) and seeds contain up to $34 \%$ oil. All these components of the JCL fruit can be, and have been used as sources of bioenergy. The gross energy value of the seed is $24 \mathrm{MJ} \mathrm{kg}^{-1}$, which is higher than lignite coal, cattle manure and comparable to corn cobs (Augustus and Jayabalan, 2002).

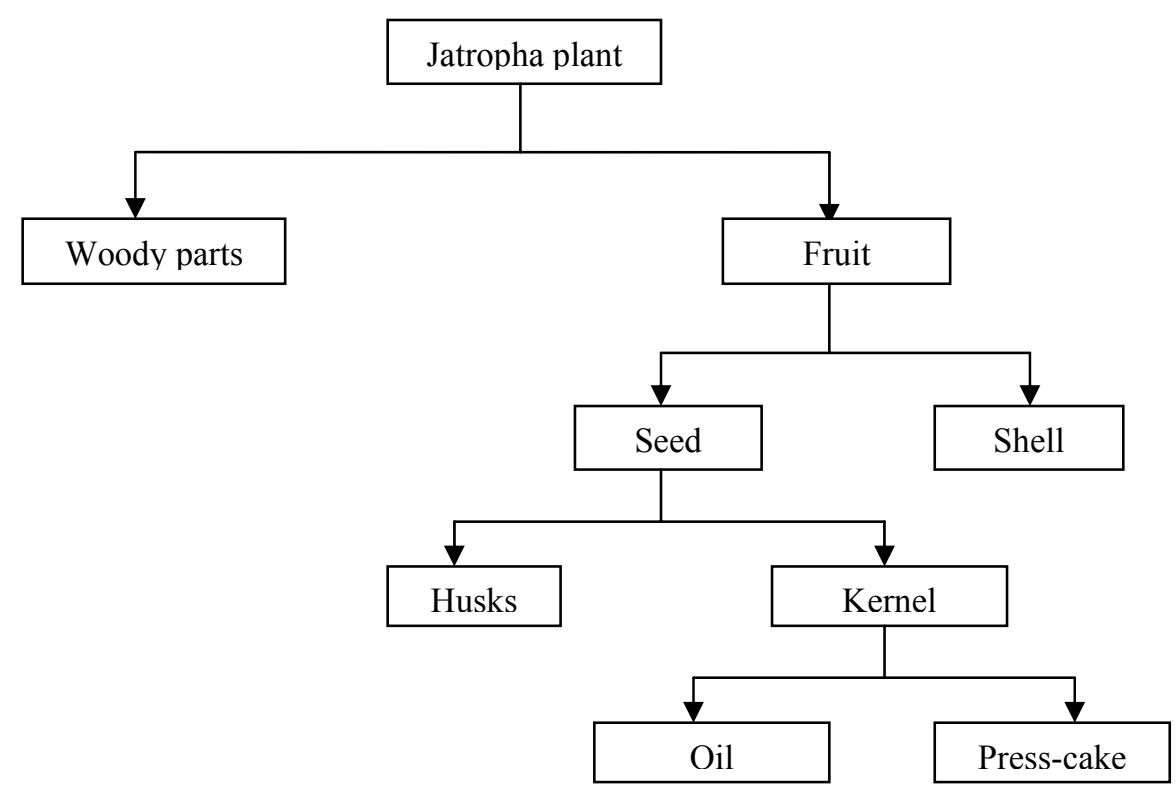

\subsection{The shell}

Figure 1. Energetic components of Jatropha curcas

The shell is mechanically removed from the fruit in the first step during oil extraction. About one tonne of shell material can be obtained from one hectare and this material can be used as a source of energy. The chemical analysis of JCL shell has shown that it is made up of $34 \%, 10 \%$ and $12 \%$ cellulose, hemicellulose and lignin, respectively (Singh et al., 2008, Abreu, 2009). Volatile matter, ash and fixed carbon content of the shell have been shown to be $69 \%, 15 \%$ and $16 \%$, respectively (Singh et al., 2008). These results show that JCL shells have very high ash content. This has an influence on the type of conversion technology that can be used to obtain energy from the shells.

Chemical breakdown of the shells by either thermo-chemical or bio-chemical processes, produces a solid residue. This residue is ash when produced by combustion in air. The ash component forms a standard measurement parameter for solid and liquid fuels and affects both the handling and processing costs of the overall biomass energy conversion cost (McKendry, 2002). Depending on the magnitude of the ash content, the available energy of the fuel is reduced proportionately (McKendry, 2002). Jatropha shell ash fuses at temperatures above $750^{\circ} \mathrm{C}$ (Singh et al., 2008). At these high temperatures the ash reacts to form a slag, which can reduce plant throughput in combustion equipment. 
The caloric value of JCL shells is $11.1 \mathrm{MJ} \mathrm{kg}^{-1}$ (Sotolongo et al., 2009). With this value and using a yield value of one tonne JCL shells per hectare, shells can supply $11.1 \mathrm{GJ} \mathrm{ha}^{-1}$. The chemical composition of JCL shells seems to suggest that it is a good feedstock for biological conversion and for briquetting (Singh et al., 2008). Several conversion technologies have been studied using JCL shells as an energy feedstock. These include briquetting and combustion (Singh et al., 2008), pyrolysis (Manurung et al., 2009) and bio-methanation (Sotolongo et al., 2009). The results of these studies are summarised in Table 1.

Table 1. Use of Jatropha curcas shells for energy purposes

\begin{tabular}{|c|c|c|}
\hline Technology & Results & Reference \\
\hline $\begin{array}{l}\text { Briquetting and combustion (briquettes } \\
\text { with diameter of } 52.2 \text { and } 25-30 \mathrm{~mm} \\
\text { used) }\end{array}$ & $\begin{array}{l}\text { - One kg of briquettes took } 35 \text { min for complete combustion } \\
\text { and gave temperatures in the range } 525-780^{\circ} \mathrm{C} \text {. } \\
\text { - Briquettes did not crumble and maintained their original } \\
\text { shape during combustion. }\end{array}$ & Singh et al., 2008 \\
\hline $\begin{array}{l}\text { Fast pyrolysis (shells valorised in a } \\
\text { continuous bench scale pyrolyser at } \\
\text { throughput of } 2.27 \mathrm{kgh}^{-1} \text { at } 480^{\circ} \mathrm{C} \text { and } \\
\text { atmospheric pressure) }\end{array}$ & $\begin{array}{l}\text { - Oil yield was } 50 \text { wt.\%, char (23 wt.\%), gas (17 wt.\%) and } \\
\text { ash. } \\
\text { - Oil was not homogenous in nature. }\end{array}$ & $\begin{array}{l}\text { Manurung et al., } \\
2009\end{array}$ \\
\hline $\begin{array}{l}\text { Anaerobic digestion (in an up flow } \\
\text { anaerobic digester with retention time } \\
\text { of } 3 \text { days) }\end{array}$ & - Considerable amounts of biogas obtained & $\begin{array}{l}\text { Sotolongo et al., } \\
2009\end{array}$ \\
\hline
\end{tabular}

Carbonization is a popular technology used to produce charcoal from woody materials. However, carbonization of JCL shells is not a recommended practice, unless there are large quantities of the material available (Benge, 2006). This is because of the low yield of solid matter of about $30 \%$ during conventional pyrolysis.

\subsection{Seed husks}

The JCL seed contains about $42 \%$ seed husks. There is limited information in literature about the use of JCL seed husks for energy purposes. Analysis of the husks by Singh et al., (2009) and Vyas and Singh (2007) showed that the husks contained 4\% ash, $71 \%$ volatile matter and $25 \%$ fixed carbon. The calorific value of the husks is $16 \mathrm{MJ} \mathrm{kg}^{-1}$, comparable to that of wood (Vyas and Singh, 2007). The physical properties of husks (for example. bulk density of $223 \mathrm{~kg} \mathrm{~m}^{-3}$ ) make them amenable to briquetting. The briquettes can be used as an energy source via combustion.

Gasification is a mature commercial energy conversion technology that can be used with seed husks. The JCL seed husks have been converted to syngas in an open core down draft gasifier (Vyas and Signh, 2007). In this study, it was found that the syngas calorific value and concentration of carbon monoxide, along with gasification efficiency increased with the increase in gas flow rate. This study showed that seed husks can be successfully used as feedstock for open core down draft gasifier.

\subsection{Raw Seed oil}

Seeds contain about $35 \%$ oil which can be extracted by heat, solvents or by pressure. About $900 \mathrm{~kg}$ of oil can be obtained from a hectare. The seed oil is potentially the most valuable end-product of JCL. Seed oil from JCL has been extensively studied as an alternative stationary engine or transportation fuel (Achten et al., 2008). This is due to its potential to substitute fossil diesel. The calorific value of seed oil is $39 \mathrm{MJ} \mathrm{kg}^{-1}$ (Sotolongo et al., 2009)]. This is higher than anthracite coal and comparable to crude oil.

Raw oil has been used as a substitute for petro-diesel both in modified and unmodified diesel engines. The fuel properties of seed oil are shown in Table 2. It can be seen from Table 2 that seed oil has high kinematic viscosity. The viscosity of raw oil is 41.5 $\mathrm{mm}^{2} \mathrm{sec}^{-1}$ compared to the ASTM standard requirement for diesel fuel which is 1.3-4.1 mm $\mathrm{sec}^{-1}$ (Kywe and Oo, 2009). Resultantly, the use of raw oil in diesel engines has not shown satisfactory results due to this high viscosity (Shahid and Jamal, 2008). High viscosity of raw oil causes problems in its use in diesel engines. These include reducing the fuel atomization and increasing fuel spray, which would be responsible for engine deposits, injector coking, piston ring sticking and thickening of lubricating oil (Kywe and Oo, 2009; Shahid and Jamal, 2008).

Despite the problems caused by its high viscosity for use in diesel engines, raw oil can have some other energy uses. It has been used in slow-speed stationary diesel engines such as pumps and generators with success (Tomomatsu and Brent, 2007). Prasad et al. (2000) reported that tests with low heat rejection diesel engine showed that use of JCL oil results in higher brake specific energy consumption (BSEC), lower brake thermal efficiency (BTE), higher exhaust gas temperature (EGT) and lower $\mathrm{NO}_{\mathrm{x}}$ emissions than fossil diesel. The reduction in $\mathrm{NO}_{\mathrm{x}}$ emission has environmental benefits.

Pre-heating and blending raw oil with fossil diesel are techniques that have also been used to improve the use of raw JCL as a fuel (Achten et al., 2008). Both techniques have the effect of reducing the viscosity of the seed oil. Raw oil can also be used as a substitute for kerosene in lamps and cooking stoves. However, these will need to be modified to account for high oil viscosity and 
low absorbance capacity (Tomomatsu and Brent, 2007). Thus, combustion in stationary diesel engines, cooking stoves and lighting lamps are the most common uses of raw JCL oil.

\subsection{Biodiesel production from Jatropha curcas seed oil}

The JCL seed oil is made up of a high content of unsaturated fatty acids (78-84\%) which makes the oil suitable for biodiesel production (Salimon and Abdullah, 2008). Biodiesel is made from vegetable oils and animal fats. Trans-esterification is the commonest technology in use today to produce biodiesel from JCL oil. In this process, JCL oil is converted under heat to esters, usually methyl esters and glycerine by alcohol (usually methanol) and a strong base catalyst (sodium hydroxide) (Singh et al., 2008). The process is normally a sequence of three consecutive reversible reactions. In the first step triglycerides are converted to diglycerides, and diglycerides to monoglycerides and monoglycerides to glycerine. Esters are produced in all the three reactions. Process variables in trans-esterification include reaction temperature, ratio of alcohol to oil, amount and type of catalyst, mixing intensity and type of raw oil (Marchetti et al., 2007). The catalysts can be alkali, acid, supercritical alcohol or lipases. The stoicheometric ratio of alcohol and oil is usually 3:1 (Marchetti et al., 2007) or the alcohol is added at 15\% by weight (Francis et al., 2005). Ethanol is preferred as it is obtained from natural raw materials and thus is renewable and $\mathrm{CO}_{2}$ neutral. There is a correlation between seed oil content and the amount of biodiesel produced. Trans-esterification processes yield biodiesel in the range $92-98 \%$ of the original oil. This would give about $828 \mathrm{~kg}$ of biodiesel ha ${ }^{-1}$, representing about 32GJ of energy ha ${ }^{-1}$.

The suitability of Jatropha oil for trans-esterification into biodiesel has been clearly demonstrated (Achten et al., 2008; Shahid and Jamal, 2008). The issue is about the economic feasibility of the system. For African countries, the feasibility of the production of biodiesel from Jatropha oil was studied by Eisa (1997) and Foidl and Eder (1997).The economic evaluation showed that biodiesel production from Jatropha is profitable provided the by-products of the biodiesel production process can be sold as valuable products (Foidl and Eder, 1997). It is important to note that African countries, like Zimbabwe, have set up commercial plants for production of biodiesel from JCL oil.

Table 2. Fuel properties of raw Jatropha seed oil

\begin{tabular}{|l|c|l|}
\hline \multicolumn{1}{|c|}{ Properties } & Values & \multicolumn{1}{c|}{ Reference } \\
\hline Calorific value $\left(\mathrm{MJ} \mathrm{kg}^{-1}\right)$ & 39.77 & Kumar and Sharma (2008) \\
\hline Kinematic viscosity at $40^{\circ} \mathrm{C}\left(\mathrm{mm}^{2} \mathrm{sec}^{-1}\right)$ & 41.51 & Kywe and Oo (2009) \\
\hline Cloud point $\left({ }^{\circ} \mathrm{C}\right)$ & 2 & Achten et al. $(2008)$ \\
\hline Sulphur content $(\% \mathrm{wt})$ & 0.04 & Abreu (2009) \\
\hline Specific gravity & 0.87 & Kywe and Oo, 2009 \\
\hline Cetane number & $40-45$ & Kumar and Sharma (2008) \\
\hline Relationship C/H (\% wt) & 13.11 & Abreu (2009) \\
\hline Flash point $\left({ }^{\circ} \mathrm{C}\right)$ & 235 & Achten et al. $(2008)$ \\
\hline
\end{tabular}

Biodiesel production from plant oil by trans-esterification is a mature commercial technology. However, studies continue to be carried out to produce biodiesel from JCL with high free fatty acid (FFA) content (15\%). For example, Berchmans and Hirata (2008) have developed a two-stage trans-esterification process to improve methyl ester yield from Jatropha with high content of FFA. In addition, in order to reduce the cost of biodiesel production, bio-catalysts such as lipase enzymes from Rhizopus oryzae have been evaluated and found to have potential to be used in biodiesel production (Tamalampudi et al., 2008). Alternative ways of trans-esterification have also been investigated. These include trans-esterification using a solid super base catalyst (Zhu et al., 2006), in-situ trans-esterification skipping the oil extraction step (Harvey et al., 2007), trans-esterification in supercritical; alcohols and biodiesel synthesized enzymatically in the presence of supercritical $\mathrm{CO}_{2}$ (Rathore and Madras, 2007).

The use of Jatropha biodiesel in compression ignition engines, both in pure form or blended with petro-diesel is well documented (Shahid and Jamal, 2008). Pure biodiesel (B100) and its blends with petro-diesel can be used in any petroleum diesel engine without the need for modification. Prasad et al. (2000) concluded that the use of trans-esterified JCL oil achieves similar results as the use of fossil diesel, although it causes less $\mathrm{NO}_{\mathrm{x}}$ emissions. The characteristics of Jatropha biodiesel compared to the European standards for diesel fuel are shown in Table 3. It can be seen from Table 3 that biodiesel has properties similar to petrodiesel. With the current emphasis on alternative renewable fuels, biodiesel is likely to be a major fuel in the near future.

\subsection{Press-cake}

After oil extraction from the seeds a residue matter or cake remains as a by-product. Generally, about $50 \%$ or up to $75 \%$ of the weight of seeds remains as press-cake (Staubmann et al., 1997, Singh et al., 2008). This press-cake contains mainly proteins and carbohydrates. The cake is made up of the seed husks (42\%) and kernel (Abreu, 2009). Based on the extraction efficiencies and the average oil content of the whole seed, press-cake can contain 9-12\% oil by weight (Achten et al., 2008). This oil influences the gross energy value of press-cake, which is about $18.2 \mathrm{MJ} \mathrm{kg}^{-1}$ (Achten et al., 2008). Nitrogen, phosphorus and potassium levels of the cake are 6\%,2.8\% and 0.9\%, respectively (Del Greco and Rademaker, 1998). Press cake has 94\% total solids, out of which $93 \%$ is volatile solids. About one $\mathrm{t} \mathrm{ha}^{-1}$ of press-cake can be obtained, representing about $18.2 \mathrm{GJ}$ of energy per hectare. 
The press-cake is high in organic matter and has good potential for biogas production. The press-cake contains adequate amounts of carbohydrates and proteins for digestion by anaerobic bacteria to produce large amounts of biogas. Production of biogas by anaerobic digestion of Jatropha press-cake has been demonstrated (Singh et al., 2008, Staubman et al., 1997). Staubman et al (1997) obtained $0.446 \mathrm{~m}^{3}$ of biogas containing $70 \%$ methane per $\mathrm{kg}$ of dry seed press-cake using pig manure as inoculum. Elsewhere, Radhakrishma (2007) obtained $0.5 \mathrm{~m}^{3}$ biogas kg-1 of solvent extracted press-cake and $0.6 \mathrm{~m}^{3}$ biogas $^{-1} \mathrm{~kg}^{-1}$ of mechanically de-oiled cake. Singh et al (2008) observed that biogas production from JCL press-cake was about $60 \%$ higher than that from cattle dung and contained $66 \%$ methane.

Table 3. Characteristics of Jatropha biodiesel compared to European standards for diesel fuel (Marchetti et al., 2007)

\begin{tabular}{|l|c|c|}
\hline \multicolumn{1}{|c|}{ Characteristic } & Jatropha biodiesel & European standard \\
\hline Density $\left(\mathrm{g} \mathrm{cm}^{-3}\right.$ at $\left.20^{\circ} \mathrm{C}\right)$ & 0.87 & $0.86-0.90$ \\
\hline Flash point $\left({ }^{\circ} \mathrm{C}\right)$ & 191 & $>101$ \\
\hline Cetane No. $(\mathrm{ISO} 5165)$ & $57-62$ & $>51$ \\
\hline Kinematic viscosity $\left(\mathrm{mm}^{2} \mathrm{sec}^{-1}\right.$ at $\left.40^{\circ} \mathrm{C}\right)$ & 4.20 & $3.5-5$ \\
\hline Calorific value $\left(\mathrm{MJ} \mathrm{kg}^{-1}\right)$ & 39.5 & - \\
\hline Iodine No. & $95-106$ & $<120$ \\
\hline Sulphated ash & 0.014 & $<0.02$ \\
\hline Carbon residue & 0.025 & $<0.3$ \\
\hline
\end{tabular}

Anaerobic digestion is an extensively used technology and can be used to convert press-cake into biogas. Biogas is a robust renewable fuel that can be used to supply heat, electricity, process steam and methanol. As stated earlier, JCL press-cake has been demonstrated to be good substrate for biogas production (Staubman et al., 1997). In order to avoid the limitation of availability of the press-cake, co-digestion of JCL press-cake with other substrates can be a viable alternative. Co-digestion is the simultaneous digestion of a homogenous mixture of two or more substrates. For example, biogas production from manure alone (which has a relatively low gas yield) is normally not economically viable. Addition of co-substrates with a high methane potential, such as the JCL press-cake, will increase the biogas yield.

Pyrolysis is one of the most promising thermochemical conversion technologies for recovering energy from biomass. It is a well developed technology that has also been experimented with JCL press-cake. Jatropha press-cake is a good substrate for production of biofuels via pyrolytic processes (Demirbaş, 2002). The major components of the press-cake are hemicellulose, cellulose, and lignin. These can be broken down during pyrolysis to produce bio-oils, gas and char. These products of pyrolysis are important energy carriers.

As the production of biodiesel from Jatropha increases, its residue materials in terms of shells and press-cake are anticipated to increase. Pyrolysis is a viable technology to convert these residues into value added energy carriers. Thermogravimetric analysis (TGA) has been used to determine the thermal degradation properties of Jatropha residues and its product yields have been determined (Demirbaş, 2002). Typical product yields of pyrolytic degradation of JCL press-cake are shown in Table 4 . Noteworthy is the increase in the production of hydrogen with increased temperature. Thus, hydrogen can be produced directly through pyrolysis at high temperatures. Hydrogen is a clean energy carrier with a high calorific value (142 $\left.\mathrm{MJ} \mathrm{kg}^{-1}\right)$.

Table 4. Product yields from pyrolysis of Jatropha seed residues (Demirbaş, 2002)

\begin{tabular}{|c|c|c|c|c|}
\hline Temperature $\left({ }^{\circ} \mathrm{C}\right)$ & \multicolumn{3}{|c|}{ Yields of products (wt.\%) } & Hydrogen (vol.\%) \\
\hline & Solids & Oil & Gas & 8.22 \\
\hline 500 & 63.9 & 23.2 & 12.9 & 9.29 \\
\hline 700 & 61.2 & 15.1 & 23.7 & 11.63 \\
\hline 900 & 56.5 & 13.3 & 30.2 & \\
\hline
\end{tabular}

\subsection{Woody products}

Wood is a widely used source of energy. Pruning is a common practice in Jatropha production as it is used to manage canopy growth and promote lateral branching. On average, there are about 2,500 Jatropha trees ha ${ }^{-1}$ (Gour, 2006). Pruning of these trees produces substantial amounts of wood. Over a period of 6 years, more than $20 \mathrm{t}$ of woody biomass can be produced in one hectare of Jatropha plantation from pruning (Sotolongo et al., 2009). In addition, it is common practice to cut down Jatropha trees to a height of $45 \mathrm{~cm}$ once every 10 years to allow for re-growth. This practice provides additional wood from Jatropha plantations. Each Jatropha plant produces about $200 \mathrm{~kg}$ of biomass with dry matter content of about $25 \%$ at about 7 years of growth (Benge, 2006). This yields a dry matter content of wood of about $80 \mathrm{t} \mathrm{ha}^{-1}$ in cuttings done once every 10 years. With an energy content of $15.5 \mathrm{MJ} \mathrm{kg}^{-1}$ (Sotolongo et al., 2009) this has the potential to supply 1.2 PJ of energy. This wood, together with materials obtained from pruning can provide fuelwood. However, Jatropha wood is light wood with a density of 0.35 and is not good for both fuel wood and charcoal (Benge, 2006). The wood burns so quickly that the use of Jatropha for fuelwood or charcoal can only be minimal. 


\section{Jatropha Energy Model}

\subsection{Total Energy Output}

The value of JCL as a source of energy has been illustrated above. Table 5 summarises the various components of JCL that can be used for energy purposes and the associated conversion technologies. The multiplicity of energetic components of JCL makes a valuable source of both first and second generation biofuels.

\subsection{Net Energy Output}

When converting energy from one form to another more useful form the second law of thermodynamics dictates that some energy will be lost. Net energy gain (NEG), the difference between the total energy outputs and total energy inputs, is one of the accepted indices for analysing the energy efficiency of biofuels (Nguyen et al., 2007). Net energy ratio (NER), the ratio of total energy outputs to total energy inputs is also an indicator for comparing the energy efficiency of biofuels.

Life cycle analysis of JCL have shown that it has it has positive net energy gain (Greenergy, 2009; Prueksakorn and Gheewala, 2008; Prueksakorn, et al., 2010). The NER ratio of JCL depends on whether the plantation is perennial or annual. Prueksakorn et al (2010) reported NER values of 6 and 7.5 for perennial and annual plantations, respectively. Taking total energy output of 121.2 GJ given in Table 5, the net energy value will be $101 \mathrm{GJ}$ for a perennial plantation.

Table 5. An energy model for Jatropha curcas L.

\begin{tabular}{|c|c|c|c|c|}
\hline Component & $\begin{array}{l}\text { Quantities } \\
\left(\text { tonnes ha }^{-1}\right)\end{array}$ & Energy value $\left(\mathrm{MJ} \mathrm{kg}^{-1}\right)$ & Total energy $\mathrm{ha}^{-1}(\mathrm{GJ})$ & Conversion technology \\
\hline Shells & 1 & 11.1 & 11.1 & $\begin{array}{l}\text { - Combustion } \\
\text { - Pyrolysis } \\
\text { - Anaerobic digestion }\end{array}$ \\
\hline Seed husks & 0.6 & 16 & 9.6 & $\begin{array}{l}\text { - Briquetting } \\
\text { - gasification }\end{array}$ \\
\hline Raw seed oil & 0.9 & 39.8 & 35.8 & $\begin{array}{l}\text { - Combustion (direct) } \\
\text { - Trans-esterification }\end{array}$ \\
\hline Press-cake & 1 & 18.2 & 18.2 & $\begin{array}{l}\text { - Anaerobic digestion } \\
\text { - Pyrolysis }\end{array}$ \\
\hline Woody products & 3 & 15.5 & 46.5 & - Combustion \\
\hline Total & & & 121.2 & \\
\hline
\end{tabular}

\section{Conclusion}

Jatropha curcas L. is a robust energy crop with a lot of potential to supply multiple energy carriers. This paper has provided a review of the possible energy carriers that can be obtained from JCL. The possibilities exist to obtain solid, liquid and gaseous energy products from JCL with the use of appropriate conversion technologies. Technological options are available to broaden the energy carrier matrix from JCL, extending from biodiesel to other potent energy carriers such as biogas and pyrolytic products. The diversity of technological options and multiplicity of JCL processing products, provide an opportunity for a zero-waste approach to JCL utility as an energy crop. Both first generation energy carriers such as biodiesel and second generation energy carriers such as pyrolytic oils and syngas can be obtained from different products of JCL.

\section{References}

Abreu, F., 2009, Alternative by-products from Jatropha. Download, http://www.ifad.org/events/jatropha/harvest/f_Abreu.ppt; 2009.

Achten W.M.J., Verchot, L., Franken, Y.J., Mathijs, E., Singh, V.P., Aerts, R. And Muys B., 2008, Jatropha biodiesel production and use. Biomass and Bioenergy, Vol. 32, pp. 1063-1084.

Augustus, G.D.P. and Jayabalan M., 2002, Evaluation and bioinduction of energy components of Jatropha curcas. Biomass and Bioenergy, Vol. 23, pp. 161-164.

Benge, M., 2006, Assessment of the potential of Jatropha curcas, (biodiesel tree) for energy production and other uses in developing countries. Download, Http: \|www.echotech.org.

Berchmans, H.J. and Hirata, S., 2008, Biodiesel production from crude Jatropha curcas L. seed oil with a high content of free fatty acids. Bioresource Technology, Vol. 99, pp. 1716-1721.

Del Greco, G.V. and Rademaker, L., 1998, The Jatropha energy system: An integrated approach to decentralised and sustainable energy production at the village level. Workshop on the potential of Jatropha curcas in rural development and environment protection. Harare, 1998 May 13-15. 
Demirbaş, A. and Demirbaş, M.F., 2003, Biomass and wastes: Upgrading alternative fuels. Energy Sources, Vol. 25, pp. 317-329.

Demirbaş, A., 2002, Gaseous products from biomass by pyrolysis and gasification: effects of catalyst on hydrogen yield. Energy Conversion and Management, Vol. 43, pp. 897-909.

Eisa, M.N., 1997, Production of ethyl esters as diesel fuel substitutes in the developing countries. In: Gubitz, G.M., Mittelbach, M., Trabi, M. (Eds.), Biofuels and Industrial Products from Jatropha curcas. DBV Graz, pp.110-112.

Foidl, N. and Eder, P.,1997, Agro-industrial exploitation of J. Curcas. In: Gubitz, G.M., Mittelbach, M., Trabi, M. (Eds.), Biofuels and Industrial Products from Jatropha curcas. DBV Graz, pp. 88-91.

Francis, G., Edinger, R. and Becker, K.., 2005, A concept for simultaneous wasteland reclamation, fuel production, and socioeconomic development in degraded areas in India: Need, potential and perspectives of Jatropha plantations. Natural Resources Forum, Vol. 29, pp. 12-24.

Gour, V.K., 2006, Production practices including post harvest management of Jatropha curcas. In: B. Singh, R. Swaminathan, V. Ponraj (Eds.), Biodiesel Conference Towards Energy Independence - Focus on Jatropha, Rashtrapati Nilayam, Bolaram, Hyderabad; 9-10 June, pp. 223-251.

Greenergy. Jatropha, 2009 - A greenergy perspective. Download, http://www.greenergy.com/perspective/Jatropha.pdf.

Gunaseelan, V.N., 2009, Biomass estimates, characteristics, biochemical methane potential, kinetics and energy flow from Jatropha curcas on dry lands. Biomass and Bioenergy, Vol. 33, pp. 589-596.

Harvey, A.P., Khurana, R. And Lee J.G.M., 2007, In-situ trans-esterification of Jatropha curcas seed to produce biodiesel, using a mixture of alcohols. In: Proceedings of the fourth international biofuels conference, New Delhi, India, February 1-2: Winrock International India, pp. 187-193.

Kumar, A. and Sharma, S., An evaluation of multipurpose oil seed crop for industrial uses (Jatropha curcas L.): A review. Indian Crops and Products, Vol. 28, pp. 1-10.

Kumar, S., Gupta, A.K. and Naik, S.N. 2003, Conversion of non-edible oil into biodiesel. Journal Sci. Ind. Res., Vol. 62, pp. 124132.

Kumar, A. And Sharma, S., 2008, An evaluation of multipurpose oil seed crop for industrial uses (Jatropha curcas L.): a review. Industrial Crops and Products, Vol. 28, pp. 1-10.

Kywe, T.T. and Oo, M,M., 2009, Production of biodiesel from Jatropha oil (Jatropha curcas) in pilot plant. Proceedings of World Academy of Science, Engineering and Technology, Vol. 38, pp. 481-487.

Marchetti ,J.M., Miguel, V.U. and Errazu, A.F., 2007, Possible methods for biodiesel production. Renewable and Sustainable Energy Reviews, Vol. 11, pp. 1300-1311.

McKendry, P., 2002, Energy production from biomass (part 2): conversion technologies. Bioresource Technology, Vol. 83, pp. 4754.

McKendry, P., 2002, Energy production from biomass (part 1): overview of biomass. Bioresource Technology, Vol. 83, pp. 37- 46.

Manurung, R., Wever, D.A.Z., Wildschut, J., Venderbosch, R.H., Hidayat, H., van Dam, J.E.G., Leijenhorst, E.J., Broekhuis, A.A. and Heeres, H.J., 2009, Valorisation of Jatropha curcas L. parts: Nut shell conversion to fast pyrolysis oil. Food and Bioproducts Processing, Vol. 87, pp. 187-196.

Nguyen, T.L.T., Gheewala, S.H. and Garivait, S. 2007, Full chain energy analysis of fuel ethanol from cassava in Thailand. Environmental Science and Technology, Vol. 41, pp. 4135-4142.

Prasad, C.M.V., Krishma, M.V.S.M., Reddy, C.P. and Mohan, K.R., 2000, Performance evaluation of non-edible vegetable oils as substitute fuels in low heat rejection diesel engines. Proceedings of the Institution of Mechanical Engineers Part D, Journal of Automobile Engineering, Vol. 214, pp. 181-187.

Prueksakorn, K. And Gheewala, S.H. 2008. Full chain analysis of biodiesel from Jatropha curcas L. in Thailand. Environmental Science and Technology, Vol. 42, pp. 3388-3393.

Preuksakorn, K., Gheewala, S.H., Malakul, P. And Bonnet, S., 2010. Energy analysis of Jatropha plantation systems for biodiesel production in Thailand. Energy for Sustainable Development, doi:10.1016/j.esd.2009.12.002.

Rathore, V. and Madras G., 2007, Synthesis of biodiesel from edible and non-edible oils in supercritical alcohols and enzymatic synthesis in supercritical carbon dioxide. Fuel, Vol. 86, pp. 2650-2659.

Radhakrishma, P., 2007, Contribution of de-oiled cakes in carbon sequestration and as a source of energy, in Indian agricultureneed for a policy initiative. In: Proceedings of the fourth international biofuels conference, New Delhi, India, February 1-2, New Delhi: Winrock International India, pp. 65-70.

Salimon, J. and Abdullah, R., 2008, Physicochemical properties of Malaysian Jatropha curcas seed oil. Sains Malaysian, Vol. 7, No. 4, pp. 379-82.

Shahid, E.M. and Jamal, Y., 2008. A review of biodiesel as a vehicular fuel. Renewable and Sustainable Energy Reviews, Vol. 2, No. 9, pp. 2484-94.

Singh, R.N., Vyas, D.K., Srivastava, N.S.L., and Narra M., 2008, SPERI experience on holistic approach to utilize all parts of Jatropha curcas fruit for energy. Renewable Energy, Vol. 33, pp. 1868-1873.

Sotolongo, J.A., Beatón, P., Diaz, A., de Oca, S.M., del Valle, Y., Pavón ,S.G. and Zanzi ,R, 2009, Jatropha curcas L. as a source for the production of biodiesel: A Cuban experience, Download http://hem.fyristorg.com/zanzi/paper/W2257.pdf. 
Staubmann, R., Foidl, G., Foidl, N., Gübitz, G.M., Lafferty, R.M., Arbizu, V.M.V. and Steiner, W, 1997, Biogas production from Jatropha curcas press-cake. Applied Biochemistry and Biotechnology, Vol. 63-65, pp. 457-467.

Tamalampudi, S., Talukder, M.R., Hama, S., Numata, T., Kondo, A. And Fukuda, H., 2008. Enzymatic production of biodiesel from Jatropha oil: a comparative study of immobilized-whole cell and commercial lipases as a bio-catalyst. Biochemistry Engineering Journal, Vol. 39, pp. 185-185.

Tomomatsu, Y. and Brent, S., 2007, Jatropha curcas biodiesel production in Africa: Economics and potential value chain development for smallholder farmers. WP54,. Nairobi, World Agroforestry Centre.

Vyas, D.K. and Singh, R.N., 2007, Feasiblity study of Jatropha seed husk as an open core gasifier feedstock. Renewable Energy, Vol. 32, pp. 512-517.

Zhu, H.P., Wu, Z.B., Chen, Y.X., Zhang, P., Duan, S.J. and Liu, X.H., 2006, Preparation of biodiesel catalysed by solid super base of calcium oxide and its refining process. Chinese Journal of Catalysis, Vol. 27, pp. 391-396.

\section{Biographical notes}

R. M Jingura is received his PhD in 2000 from the University of Zimbabwe. He is the Director of Research at Chinhoyi University of Technology. His research interests are in biofuels. Special focus areas include optimization of energy supply from energy crops and agricultural residues.

D. Musademba is the Acting Chairman of the Department of Fuels and Energy at Chinhoyi University of Technology. He is a lecturer in renewable energy technologies with interest in photovoltaics and biofuels.

R. Matengaifa is a Research Assistant in the Research Directorate at Chinhoyi University of Technology.

Received April 2010

Accepted May 2010

Final acceptance in revised form September 2010 